\title{
A rapid and sensitive diagnosis of bovine leukaemia virus infection using the nested shuttle polymerase chain reaction ${ }^{1}$
}

\author{
Ester T. González ${ }^{2}$, Junzo Norimine ${ }^{3}$, Alejandro R. Valera ${ }^{4}$, Gabriel Travería ${ }^{4}$, Graciela \\ A. Oliva ${ }^{2}$ and María E. Etcheverrigaray ${ }^{2}$
}

\begin{abstract}
González E.T., Norimine J., Valera A.R., Travería G.,Oliva G.A. \& Etcheverrigaray M.E. 1999. A rapid and sensitive diagnosis of bovine leukaemia virus infection using the nested shuttle polymerase chain reaction. Pesquisa Veterinária Brasileira 19(2):63-67. Facultad de Ciencias Veterinarias, Universidad Nacional de La Plata, 60 y 118, 1900 La Plata, Argentina.

Bovine leukaemia virus (BLV) is the causative agent of enzootic bovine leukosis (EBL). In Argentina, where a program to eradicate EBL has been introduced, sensitive and reliable diagnosis has attained high priority. Although the importance of the agar gel immunodiffusion test remains unchanged for routine work, an additional diagnostic technique is necessary to confirm cases of sera with equivocal results or of calves carrying maternal antibodies.Utilizing a nested shuttle polymerase chain reaction, the proviral DNA was detected from cows experimentally infected with as little as $5 \mathrm{ml}$ of whole blood from BLV seropositive cows that were nonetheless normal in haematological terms. It proved to be a very sensitive technique, since it rapidly revealed the presence of the provirus, frequently at 2 weeks postinoculation and using a two-round procedure of nested PCR taking only 3 hours. Additionally, the primers used flanked a portion of the viral genome often employed to differentiate BLV type applying BamHI digestion. It is concluded that this method might offer a highly promising diagnostic tool for BLV infection.
\end{abstract}

INDEX TERMS: Bovine leukaemia virus, diagnosis, Nested-PCR.

RESUMO.- [Diagnóstico rápido e sensível da infecção com o vírus da Leucemia Bovina através de Shuttle Nested Polymerase Chain Reaction.] O Vírus da leucemia bovina (BLV) é o agente causal da Leucose Enzoótica Bovina (EBL). Na Argentina, iniciou-se um programa de erradicação da EBL. Neste estágio, é prioritário possuir uma ferramenta de diagnóstico confiável. Embora seja indiscutível a importância do teste de agar gel imunodifusão, empregado rotineiramente no diagnóstico serológico da EBL, faz-se necessária uma técnica de diagnóstico adicional capaz de confirmar os resultados duvidosos. Foi possivel detectar ADN proviral aplicando Nested-PCR em novilhos experimentalmente infectados com pequenas doses de sangue total $(5 \mathrm{ml})$ obtidas de um bovino BLV soropositivo. Esta técnica, cujo procedimento leva 3 ho-

\footnotetext{
${ }^{1}$ Accepted for publication on May 20,1998.

${ }^{2}$ Catedra de Virología, Facultad de Ciencias Veterinarias, Universidad Nacional de La Plata (UNLP), 60 y 118, 1900 La Plata, Argentina.

${ }^{3}$ Laboratory of Immunogenetics, Department of Animal Sciences, University of Illinois at Urbana-Champaign, Urbana, Illinois 61801, USA.

${ }^{4}$ Centro de Diagnóstico Veterinario (CEDIVE), Facultad de Ciencias Veterinarias, UNLP, R. 2, Km 116, Chascomús, Buenos Aires, Argentina.
}

ras, demonstrou ser muito sensível, uma vez que foi capaz de detectar a presença do provirus duas semanas após a inoculação. Os primers utilizados são os que detectam uma porção do genoma viral que geralmente é usado para diferenciar os tipos de BLV, utilizando a digestão com BamHI. Sugerimos que este método possa ser um instrumento válido para o diagnóstico precoce da infeção pelo BLV.

TERMOS DE INDEXAÇAO: Leucose bovina, diagnóstico, Nested-PCR.

\section{INTRODUCTION}

Bovine leukaemia virus (BLV) is an exogenous retrovirus that is the causative agent of enzootic bovine leukosis (EBL). It primarily infects B cells of cattle leading to a serological response, and in some animals causes persistent lymphocytosis and/or lymphosarcoma (Kettmann et al.1994, Mirsky et al.1996, Schwartz \& Levy 1994).

BLV infection is endemic in Argentina, especially in dairy herds of the central and northern areas. In highly infected herds, more than $60 \%$ of cows are seropositive to BLV. The economic impact of BLV infection is unknown, but appears to be major due to reduced milk production, slaughterhouse condemnation of tumour bearing carcasses, and replacement 
of sick or dead animals. In the United States, the estimated loss to the dairy industry is reported to be more than $\$ 86$ million annually. (Da et al.1993).

As we have started an eradication project of BLV infection in Argentina, early diagnosis is important for the implementation of control measures, and is currently assessed by the detection of circulating antibodies against the viral envelope protein gp51. However, this approach has shortcomings in the time taken to detect antibodies and in the failure to detect antibodies in some animals. Furthermore, the possibility of decreased immune responsiveness to BLV in animals persistently infected with bovine viral diarrhoea (BVD) virus must be considered (Roberts et al.1988). Clearly a technique such as the polymerase chain reaction (PCR), which directly detects the presence of proviral DNA, has advantages over methods designed to measure host antibodies, and ought to provide a sensitive diagnostic assay, especially when antibody tests give weakly positive or equivocal results.

The aim of this study was to improve the direct diagnosis of BLV infection by applying a simple detection method based upon a nested PCR. We have used a two temperature protocol to amplify BLV proviral DNA (we call this PCR "shuttle PCR", hereafter), and it proved to be very effective for the rapid and early detection of BLV infection, which we suggest as a practical and superior method for diagnosis. Moreover, BamH1 digestion of the PCR product gives additional information about the BLV genotype.

\section{MATERIALS AND METHODS}

Experimental Animals

Two two-year old cows (06/203 and 73/71) served as donors of BLV-infected whole blood. These donor cows had been experimentally infected previously by inoculating $10 \mathrm{ml}$ of whole blood from a tumour-bearing cow and subsequently tested monthly during 3 months, consistently giving BLV antibodies after seroconversion, as determined by the agar gel immunodiffusion (AGID) test.

Six Aberdeen-Angus two-year old cows were obtained from a closed herd consisting of 300 bovines without antecedents of bovine leukosis, and giving seronegative results by the AGID test in three determinations with intervals of two months. These 6 recipient cows were also confirmed seronegative for BLV before inoculation by AGID and PCR, as described later. Whole blood from cows 06/203 and 73/ 71 were obtained in sterile heparin and administered ( 5 or $50 \mathrm{ml}$ ) subcutaneously to four recipient cows, maintaining two as controls. The scheme of inoculation is shown in Table 1. The recipient and

Table 1. Inoculants for experimental infection

\begin{tabular}{lcccc}
\hline Donor & Recipient & Route $^{\text {a }}$ & $\begin{array}{c}\text { Blood } \\
\text { vol. }\end{array}$ & $\begin{array}{c}\text { Limphocytes } \\
\text { Inoc. }\end{array}$ \\
\hline $06 / 203$ & $57 / 40$ & SC & 5 & $3.6 \times 10^{4}$ \\
& $72 / 72$ & SC & 50 & $3.6 \times 10^{5}$ \\
$73 / 71$ & $36 / 34$ & SC & 5 & $3.0 \times 10^{4}$ \\
& $56 / 64$ & SC & 50 & $3.0 \times 10^{5}$ \\
Control & $54 / 63$ & & & \\
& $92 / 65$ & & & \\
\end{tabular}

\footnotetext{
a Inoculation route, $\mathrm{SC}$ : subcutaneous.

b Microliters.
}

control cows were bled every week thereafter until 3 months after viral inoculation.

\section{Haematological examination}

Each blood sample was examinated for differential count of white cells by convetional method. Their sera and peripheral blood mononuclear cells ( PBMC) were employed for further analysis.

\section{AGID}

The AGID test (Miller \& Van der Maaten 1976) was performed on all samples at the end of the study with a commercial kit produced in our laboratory (approved by SENASA, National Service for Animal Health in Argentina). Agar plates were placed in humidified trays and incubated at room temperature for 1-3 days.

\section{Extraction of DNA}

The DNA extraction were performed essentially as reported by Kelly et al. (1993). Briefly, blood were defrosted, $35 \mathrm{ml}$ of a $10 \mathrm{mg} / \mathrm{ml}$ stock solution of proteinase $\mathrm{K}$ was added and the samples were digested in a $55{ }^{\circ} \mathrm{C}$ waterbath overnight. Samples were extracted with phenol, then with 25:24:1 phenol:chloroform:isoamyl alcohol. Fifty microliters of $5 \mathrm{M} \mathrm{NaCL}$ and $1 \mathrm{ml}$ of $100 \%$ ethanol were added, and the samples were centrifuged at $12,000 \mathrm{x}$ g for 30 minutes at 20 to $25^{\circ} \mathrm{C}$. Samples were washed once with $70 \%$ ethanol and suspended in $50 \mathrm{ml}$ of $10 \mathrm{mM}$ Tris-HCl, $1 \mathrm{mM}$ EDTA, pH 8.0.

\section{PBMC separation}

One $\mathrm{ml}$ of heparinised blood was mixed with $1.2 \mathrm{ml}$ of phosphate buffered saline (PBS), layered over Ficoll-Paque (Pharmacia, Uppsala, Sweden) in $5 \mathrm{ml}$ conical tubes and centrifuged at $1350 \mathrm{~g}$ for 30-40 min. PBMC were collected from the gradient interphase and washed three times in PBS, centrifuging once at $650 \mathrm{~g}$ for 10 min. and then twice $1200 \mathrm{~g}$ for $5 \mathrm{~min}$. The total number of PBMC of each sample was determined by conventional method.

\section{PCR amplification}

The separated PBMC were resuspended in $50 \mathrm{ml}$ of PBS without calcium and magnesium and boiled for $12 \mathrm{~min}$. Subsequently, the specimens were chilled on ice for $5 \mathrm{~min}$. and $5 \mathrm{ml}$ of each were used as templates in $50 \mathrm{ml}$ of total reaction mixture, providing a final concentration of $50 \mathrm{mM} \mathrm{KCl}, 10 \mathrm{mM}$ Tris- $\mathrm{HCl}(\mathrm{pH} 8.3$ ), $1.5 \mathrm{mM}$ $\mathrm{MgCl}_{2}, 200 \mathrm{mM}$ of each deoxynucleotide trisphosphate, $1 \mathrm{U}$ of Taq polymerase (AmpliTaq: Perkin-Elmer Cetus, Norwalk, Conn.) , $0.2 \mathrm{mM}$ of each BLV envelope (env) primer in a final volume of $50 \mathrm{ml}$. The cycling parameters used in both the first and second amplification were 30 cycles of $1 \mathrm{~min}$. at $94^{\circ} \mathrm{C}, 1 \mathrm{~min}$. at $60^{\circ} \mathrm{C}$. Aliquots $(3 \mathrm{ml})$ of the first-round PCR product were transferred to reach of $47 \mathrm{ml}$ secondround amplification mixtures. The primers used were the same as those designed by Ballagi-Pordany et al.(1992):

\section{External primers:}

OBLV-1 5' -GTG CCA AGT CTC CCA GAT ACA-3'

OBLV-6 5'- TAT AGC ACA GTC TGG GAA GGC-3'

\section{Internal primers: \\ OBLV-3 5'- CTG TAA ATG GCT ATC CTA AGA TCT ACT GGC -3' OBLV-5 5'- GAC AGA GGG AAC CCA GTC ACT GTT CAA CTG-3'}

Products of the second round PCRs were visualised with UV light after electrophoresis in $2 \%$ agarose gels and staining with ethidium bromide. To verify the identity of these products, restriction enzyme digestion was performed using 20 units of Bam HI (GIBCO BRL, 
Table 2. The time course of detection of BLV infection by indirect (Agar Gel Inmmunodiffusion - AGID) and direct (Polymerase Chain Reaction - PCR) methods

\begin{tabular}{|c|c|c|c|c|c|c|c|c|c|c|c|c|c|c|c|c|c|c|}
\hline \multirow{3}{*}{ Recipient } & \multirow{3}{*}{ Blood vola } & \multirow{3}{*}{ Route $^{b}$} & \multirow{3}{*}{$\mathrm{ID}^{\mathrm{c}}$} & \multirow{3}{*}{ PCR } & \multicolumn{14}{|c|}{ Weeks postinoculation } \\
\hline & & & & & \multicolumn{2}{|r|}{1} & \multicolumn{2}{|r|}{2} & \multicolumn{2}{|r|}{3} & \multicolumn{2}{|r|}{4} & \multicolumn{2}{|r|}{5} & \multicolumn{2}{|c|}{6} & \multicolumn{2}{|c|}{7} \\
\hline & & & & & ID & PCR & ID & PCR & ID & PCR & ID & PCR & ID & PCR & ID & PCR & ID & PCR \\
\hline $36 / 34$ & 5 & SC & - & - & - & - & - & + & - & + & -+ & + & -+ & + & -+ & + & -+ & + \\
\hline $56 / 64$ & 50 & SC & - & - & - & - & - & + & - & + & -+ & + & + & + & + & + & + & + \\
\hline $57 / 40$ & 5 & SC & - & - & - & - & - & + & - & + & + & + & + & + & + & + & + & + \\
\hline $72 / 72$ & 50 & SC & - & - & - & - & - & - & - & + & - & + & - & + & -+ & + & + & + \\
\hline Control & & & - & - & - & - & - & - & - & - & - & - & - & - & - & - & - & - \\
\hline Control & & & - & - & - & - & - & - & - & - & - & - & - & - & - & - & - & - \\
\hline
\end{tabular}

Gaithersburg, MD) and $10 \mathrm{ml}$ of a second-round product in a final volume of $50 \mathrm{ml}$. Five $\mathrm{ml}$ of the PCR product and $20 \mathrm{ml}$ of digested DNA product were subjected to electrophoresis in a $6 \%$ acrylamide gel to characterise the 2 fragments.

\section{RESULTS}

AGID test and haematological examination

As shown in Table 2, the seroconversion was detected in three cases out of 4 experimentally-infected cows at 4 weeks after inoculation using our AGID test kit, and in the remaining case at 6 weeks. One case (36/34) was always weakly positive throughout the study. The time of seroconversion was not related with the amount of inoculant. Haematological findings were unchanged in all cows during this study (data not shown).

\section{Nested shuttle PCR}

In three out of four cows, proviral DNA was detected at 2 weeks, and in one at 3 weeks after inoculation using the nested shuttle PCR. This early detection was also independent of the dose of inoculation. We tested $57^{\circ} \mathrm{C}$ and $60^{\circ} \mathrm{C}$ as annealing plus extension temperatures, and sensitivities were not different between them (data not shown). By using $60^{\circ} \mathrm{C}$ as the temperature, the results were consistent with additional experiments using samples from BLV-seropositive

Table 3. Comparison of the sequence of the BamHI site in the portions flanked by the second primers in BLV env gene among strains isolated in various countries. From the data of Mamoun et al. (1990) and C'oulston et al. (1990)

\begin{tabular}{|c|c|c|}
\hline \multirow{2}{*}{$\begin{array}{c}\text { BLV } \\
\text { isolates }\end{array}$} & \multirow[t]{2}{*}{ Origin } & Sequences In BamHI site \\
\hline & & 5221 \\
\hline FLK-BLVUSA & USA & ATCAAGGATCCTTTTA \\
\hline VdM & USA & - \\
\hline 1BLV-1 & Japan & - \\
\hline pBLV-A1 & Australia & - - - G - - A - . . . \\
\hline LB285 & Belgium & - \\
\hline T15-2 & Belgium & - \\
\hline \multirow[t]{2}{*}{ LB59 } & France & \\
\hline & Argentina & - A - - \\
\hline
\end{tabular}

field cows. Proviral DNA could be frequently be detected from $5 \mathrm{ml}$ of supernatant of boiled $10^{4}$ PBMC from a cow as early as 2 weeks postinoculation. Supernatants of boiled samples were not different from extracted DNA as a source of template, and may even have given more consistent results.

According to the nucleotide sequence of BLV (Sagata et al.1985), we digested the final PCR products with BamH1 and confirmed the BamH1 site. Interestingly, European BLV strains reportedly do not have this restriction site (Mamoun et al. 1990, Coulston et al. 1990). As shown in Fig.1 and according with Mamoun et al (1990), we may classify BLV strains using BamHI. Argentine strains of BLV seem to belong to the

\section{BLV BLVI BamHI}

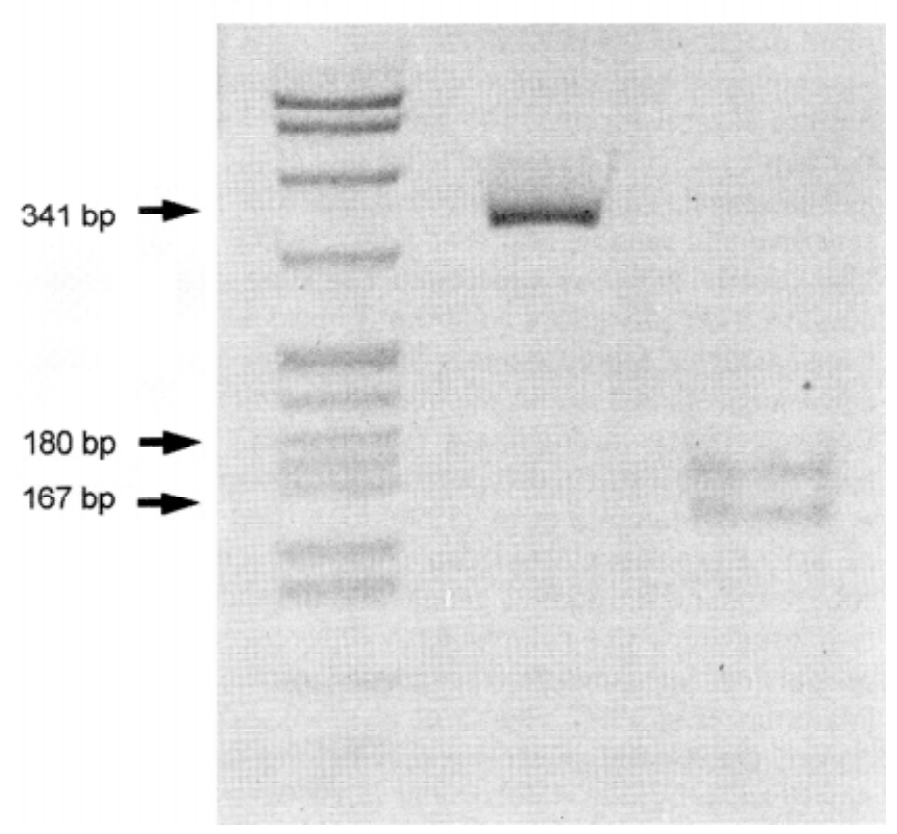

Fig. 1. Detection of BLV proviral DNA by using the nested shuttle PCR and fragments of the product digested with BamHI. Ten $\mathrm{ml}$ of the sample were loaded per well, electrophoresed on a $6 \%$ acrylamide gel and stained with ethidium bromide. Lane: 1, molecular marker, pBR322 digested with Mspl; 2 , an amplified product ; 3 , fragments of an amplified product digested with BamHI. 
Japanese-America subgroup. We also compared with the results reported by Coulston et al. (1990) for Australian strain, that belong to the same subgroup (Table 3), demostrating a high level of amino acid conservation in this biologically importante region.

\section{DISCUSSION}

Although a serological screening method, the AGID test is very economic, simple and comparatively reliable for the diagnosis of BLV infection; while its importance remains unchanged, it is not sufficiently sensitive for determining BLVstatus in some circumstances, as well as being incapable of discriminating infection from adoptive immunity in young calves born from infected cows. Also it was demonstrated that in cattle persistently infected with BVD virus, a depressed antibody response to BLV occurred and should be considered when formulating regulations governing the testing of animals for freedom from BLV (Roberts et al.1988). Conducting BLV proviral DNA detection using PCR together with the AGID test, we can eradicate these problems, whereupon sensitive and rapid diagnosis of BLV infection becomes possible.

Detection of BLV RNA or proviral DNA using PCR has so far been reported in many laboratories (Abbot et al.1988, Brandon et al.1991, Eaves et al.1994, Jacobs et al.1992, Kelly et al.1993, Klintevall et al.1994, Marsolais et al.1994, Mirsky et al.1993, Naif et al.1990, Poon et al.1993). To attain high sensitivity, a nested PCR or a southern blotting for detecting amplified products is commonly used. Naif et al.(1992) also reported an enzyme-linked assay for PCR-amplified proviral DNA (17).

As our purpose is to establish a practical, sensitive and rapid diagnosis for BLV infection and use it for field survey, we employed a simple nested PCR as BLV provirus detection. Among several reports, the method developed by BallagiPordany et al. (1992) seemed to be one of the more sensitive and practical. We have confirmed that the method is very sensitive and reliable and that a shuttle PCR is appropriate. The shuttle PCR has shortened the time of the 2-round amplification procedure to about 3 hours without reducing the sensitivity. Moreover, this final amplified product has a convenient BamHI site in the middle to confirm BLV proviral DNA specificity. Interestingly, European BLV strains do not have the BamHI site in this portion (Kettmann et al.1981,Rice et al.1984). Mamoun et al. (1990) identified two subgroups of BLV, a Japonese-American subgroup and a European subgroup, and found that genetical differences between the two subgroups are related with differences in biological properties, for example, recognition of the cell receptors (Mamoun et al.1990, Sagata et al.1985). According to this report, the Australian strain may belong to the Japonese American subgroup (Coulston et al.1990), and it has a similar mutation in the sequences associated with biological functions (neutralizable conformational epitopes: F,G and $\mathrm{H}$, also involved in syncytium inhibition ). In the present study, although we do not have sequence data, we can predict that the Argentine-type isolate also seems to belong to the Japanese-American subgroup. Dube et al. (1997), have recently reported the phylogeny of BLV using a BLV specific PCR assay, and provided very useful information about the highly conserved BLV sequences in the env gene.

There was no striking difference in the time course from infection to seroconversion or in the detection of the proviral DNA among the four inoculated-cows; 4 to 6 weeks for antibodies detected by AGID test and 2 to 3 weeks to detect proviral DNA by nested shuttle PCR.The detection of antibodies to BLV by using our AGID test kit seemed to be comparatively sensitive, because inoculants used were derived from the BLV positive cow with normal white blood cell counts and the amount of inoculants was as low as $5 \mathrm{ml}$., estimated to be $3 \times 10^{4}$ of PBMC. Naif et al.(1992) reported that they could not detect the BLV antibody from cows experimentally infected with $10^{7}$ lymphocytes of a persistently infected cow up to 4 weeks postinoculation.

Taken together, we consider that the detection of proviral DNA at 2 weeks postinoculation in our experimental infection is sufficiently sensitive to apply during the very early infection period.

In conclusion, we have shown that this protocol of the nested shuttle PCR is very useful in many aspects, and suggest that this method can be very promising and desirable for the diagnosis of BLV infection

Acknowledgments.- This work was supported by grants of the Secretary of Sciences and Technology, La Plata University and Japan International Cooperation Agency. The authors thank Dr. John Rogers and Dr. G.E. Freneau for their valuable assistance.

\section{REFERENCES}

Abbot A.A., Poesz B.J., Byrne B.C., Kwok S., Sninsky J.J. \& Erlich G.D. 1988. Enzyme gene amplifications: quantitative methods for detecting proviral DNA amplified in vitro. J. Infect. Dis. 158:1158-1169.

Ballagi-Pordany A., Klintevall K., Merza M., Klingeborn B. \& Belak S. 1992. Direct detection of bovine leukemia virus infection: practical applicability of double polymerase chain reaction. J. Vet. Med. B 39:69-77.

Brandon R.B., Naif H., Daniel R.C.W. \& Lavin M.F. 1991. Early detection of bovine leukosis virus DNA in infected sheep using the polymerase chain reaction. Res. Vet. Sci. 50:89-94.

Coulston J., Naif H., Brandon R., Kumar S., Khan S., Daniel R.C.W. \& Lavin M.F. 1990. Molecular cloning and sequencing of an australian isolate of proviral bovine leukemia virus DNA: comparison with other isolated. J. Gen. Virol. 71:1737-1746.

Da Y., Shanks R.D., Stewart J. \& Lewin H.A. 1993. Milk and fat yields decline in bovine leukemia virus-infected holstein cattle with persistent lymphocytosis. Proc. Natl Acad. Sci. 90:6538-6541.

Dube S., Bachman S., Spicer T., Love J., Choi D., Esteban E., Ferrer J. \& Poiesz B. 1997. Degenerate and specific PCR assays for the detection of bovine leukaemia virus and primate $T$ cell leukaemia/ lymphoma virus pol DNA and RNA: phylogenetic comparisons of amplified sequences from cattle and primates from around the world. J. Gen. Virol. 78: 1389-1398.

Eaves F.W., Molloy J.B., Dimmock C.K. \& Eaves L.E. 1994. A field evaluation of polymerase chain reaction procedure for detection of bovine leukaemia virus proviral DNA in cattle. Vet. Microbiol. 39:313-321.

Jacobs R.M., Song Z., Poon H., Heeney J.L., Taylor J.A., Jefferson B., Vernau W. \& Valli E.O. 1992. Proviral detection and serology in bovine leukemia virusexposed normal cattle and cattle with lymphoma. Can. J. Vet. Res. 339348.

Kelly E.J., Jackson M.K., Marsolais G., Morrey J.D. \& Callan R.J. 1993. Early 
detection of bovine leukemia virus in cattle by use of polymerase chain reaction. Am. J. Vet. Res. 54:205-209.

Kettmann R., Couez D. \& Burny A. 1981. Restriction endonuclease mapping of linear unintegrated proviral DNA of bovine leukemia virus. J. Virol. 38:27-33.

Kettmann R., Burny A., Callebaut Y., Droogmans L., Mammerickx M., Willems L. \& Portetelle D. 1994. Bovine leukemia virus, p. 39-81. In: J.A. Levy (ed.) The Retroviridae. Plenum Press, NY.

Klintevall K., Ballagi-Pordany A., Nasjund K. \& Belak S. 1994. Bovine leukaemia virus: rapid detection of proviral DNA by nested PCR in blood and organs of experimentally infected calves. Vet. Microbiol. 42:191-204.

Mamoun R.Z., Morisson M., Rebeyrotte N., Busetta B., Couez D., Kettmann R., Hospital M. \& Guillemain B. 1990. Sequence variability of bovine leukemia virus env gene and its relevance to the structure and antigenicity of the glycoproteins. J. Virol. 64:4180-4188.

Marsolais G., Dubuc R., Bergeron J., Morrey J.D., Kelly E.J. \& Jackson M.K. 1993. Importance of primer selection in the application of PCR technology to the diagnosis of bovine leukemia virus. J. Vet. Diagn. Invest. 6:297-301.

Miller J.M. \& Van der Maaten M.J. 1976. Serologic detection of bovine leukemia virus infection. Vet. Microbiol. 1: 195-202.

Mirsky M.L., Da Y. \& Lewin H.A. 1993. Detection of bovine leukemia virus proviral DNA in individual cells. PCR Methods Appl. 2:333-340.

Mirsky M.L., Olmstead C.A., Da Y. \& Lewin H.A. 1996. The prevalence of proviral bovine leukemia virus in peripheral blood mononuclear cells at two subclinical stages of infection. J. Virol. 70:2178-2183.

Naif H., Brandon R.B., Daniel R.C.W. \& Lavin M.F. 1990. Bovine leukemia proviral DNA detection in cattle using the polymerase chain reaction. Vet. Microbiol. 25:117-129.

Naif H., Daniel R.C.W., Cougle W.G. \& Lavin M.F. 1992. Early detection of bovine leukaemia virus by using an enzyme-linked assay for polymerase chain reaction-amplified proviral DNA in experimentally infected cattle. J. Clin. Microbiol. 30:675-679.

Poon H., Jimenez E., Jacobs R.M., Song Z. \& Jefferson B. 1993. Detection of bovine leukemia virus RNA in serum using the polymerase chain reaction. J. Vet. Methods B39:69-77.

Rice N.R., Stephens R.M., Couez D., Deschamps J., Kettmann R., Burny A. \& Gilden R.V. 1984. The nucleotide sequence of the env gene and post-env region of bovine leukemia virus. Virology 138:82-93.

Roberts D.H., Lucas M.H., Wibberley G. \& Wescott D. 1988. Response of cattle persistently infected with bovine virus diarrhea virus to bovine leukosis virus. Vet. Rec. 122: 293-296.

Sagata N., Yasunaga T., Tsuzuku-Kawamura J., Ohishi K., Ogawa Y. \& Ikawa Y. 1985. Complete nucleotide sequence of the genome of bovine leukemia virus: its evolutionary relationship to other retrovirus. Proc. Natl Acad. Sci. 82:677681.

Schwartz I. \& Levy D. 1994. Pathobiology of bovine leukemia virus. Vet. Res. 25:521-536. 